\title{
An oat bran meal influences blood insulin levels and related gene sets in peripheral blood mononuclear cells of healthy subjects
}

\author{
Matilda Ulmius • Anna Johansson-Persson • \\ Morten Krogh • Peter Olsson • Gunilla Önning
}

Received: 26 January 2011/ Accepted: 3 May 2011/Published online: 19 May 2011

(c) Springer-Verlag 2011

\begin{abstract}
The understanding of how fibre-rich meals regulate molecular events at a gene level is limited. This pilot study aimed to investigate changes in gene expression in peripheral blood mononuclear cells (PBMCs) from healthy subjects after consumption of an oat bran-rich meal. Fifteen subjects $(8$ men and 7 women, aged 20-28 years) ingested meals with oat bran or a control meal after an overnight fast. Blood samples for analysis of postprandial glucose, insulin and triglyceride concentrations were taken during $3 \mathrm{~h}$, while PBMCs for microarray gene expression profiling from five men and five women were taken before and $2 \mathrm{~h}$ after the meal. Analysis of transcriptome data was performed with linear mixed models to determine differentially expressed genes in response either to meal intake or meal content, and enrichment analysis was used to identify functional gene sets responding to meal intake and specifically to oat bran intake. Meal intake as such affected gene expression for genes mainly involved in metabolic stress; indicating increased inflammation due to the switch from fasting to
\end{abstract}

Electronic supplementary material The online version of this article (doi:10.1007/s12263-011-0236-8) contains supplementary material, which is available to authorized users.

M. Ulmius $(\bowtie) \cdot$ A. Johansson-Persson · P. Olsson · G. Önning Biomedical Nutrition, Pure and Applied Biochemistry,

Department of Chemistry, Centre for Chemistry and Chemical Engineering, Lund University, P.O. Box 124,

22100 Lund, Sweden

e-mail: matilda.ulmius@tbiokem.lth.se

M. Krogh

Amber BioSciences AB, Lund, Sweden

M. Krogh

Computational Biology and Biological Physics, Department

of Theoretical Physics, Lund University, Lund, Sweden fed state. The oat bran meal affected gene sets associated with a lower insulin level, compared with the control meal. The gene sets included genes involved in insulin secretion and $\beta$-cell development, but also protein synthesis and genes related to cancer diseases. The oat bran meal also significantly lowered postprandial blood insulin IAUC compared to control. Further studies are needed to compare these acute effects with the long-term health effects of oat bran.

Keywords Oats - Microarray gene expression .

Peripheral mononuclear blood cells · Postprandial response

\section{Introduction}

Dietary fibre has long been known to have beneficial health effects, and several mechanisms of action have been proposed (Anderson et al. 2009). For example, intake of soluble fibre is associated with beneficial effects on and prevention of metabolic syndrome-related diseases and type 2 diabetes, due to improved glucose and insulin concentrations. The soluble fibre can also decrease blood cholesterol concentrations by mechanisms such as reduced cholesterol synthesis and increased bile acid synthesis. In epidemiological studies, dietary fibre intake has been related to reduce the risk of cancer diseases. Lowered risk of colorectal cancer has been suggested to be due to increased production of short chain fatty acids (SCFA), leading to induced apoptosis (Key and Spencer 2007) and lowered risk of breast cancer has been attributed to the reduced levels of available oestrogen by the fibre intake (Mattisson et al. 2004). Yet, the understanding of how fibre regulates molecular events at a gene or protein level is limited (Rideout et al. 2008). 
Oat bran is rich in dietary fibre, especially the soluble fibre $\beta$-glucan. $\beta$-Glucan is one of the most widely used soluble fibre, and already in 1997, the US Food and Drug Administration (FDA) approved a health claim 'that soluble fibre from whole oats, as a part of a diet low in saturated fat, cholesterol and total fat, may reduce the risk of heart disease' (US FDA 1997). Many studies have shown that intake of oat bran decreases the postprandial responses of glucose and insulin (Sadiq Butt et al. 2008; Juvonen et al. 2009). Oat is also a good source of protein, fat, vitamins and phenolic acids (Sadiq Butt et al. 2008).

Microarray technology enables a genome-wide screening for different effects of a food component on the gene expression, including a search for mechanisms of action. Microarrays allow not only analysis of differentially expressed genes that are already known to be related to a dietary effect, but also of those where no function is known or for which no involvement has been described previously (Morine et al. 2008). Few studies have been published on the health effects of dietary fibre as assessed by global gene expression and the ones available investigate the long-term effects of fibre-rich diets (Kallio et al. 2007; Theuwissen et al. 2009; Chan and Heng 2008). To our knowledge, nobody has published an investigation of the postprandial effects on gene expression after a dietary fibre-rich meal.

The aim of the present pilot study was to measure the effect on gene expression in peripheral blood mononuclear cells (PBMCs) of a meal enriched with oat bran. Linear mixed models were used for analysing the array data to study the simultaneous dependency on many factors, and gene enrichment analysis was used to find functional categories of genes for which the expression was associated with meal intake as well as intake of oat bran specifically.

\section{Materials and methods}

Study design and subjects

Breakfasts containing different fibre sources were served to healthy subjects in order to investigate the postprandial response in glucose, insulin and triglyceride concentrations, as described previously (Ulmius et al. 2009). One meal enriched with oat bran, not presented in the previous study, was selected for gene expression analysis. Meals containing oat bran or without added fibres (control meal) were served randomly and single-blinded with at least 1 week between intakes.

The subjects were recruited by advertisement at Lund University using the inclusion criteria 20-65 years of age and body mass index (BMI) $18-30 \mathrm{~kg} / \mathrm{m}^{2}$. Subjects were excluded if they reported pregnancy or breastfeeding, diabetes mellitus, hepatitis B, use of blood lipid lowering drugs or intolerance to cereals. A total of eighteen volunteers, 10 men and 8 women, were recruited and gave a written consent. An ethics approval of the study was given by the Regional Ethical Review Board in Lund, Sweden (No. 98/2007). The subjects were asked to avoid intense physical activity and intake of alcohol, pain relief tablets or nutritional supplements the day before each trial day. They were also instructed not to eat or drink after $7 \mathrm{pm}$, except tap water and supplied white wheat bread of which they ate an optional amount at $9-10 \mathrm{pm}$, the same amount on both occasions. Use of tobacco was not allowed on the trial days, and the subjects had to avoid physical activity on the way to the study centre and arrived fasting. The test meals were ingested between 6.45 and $8.30 \mathrm{am}$.

Test meals

Oat bran was supplied by Lantmännen Food R\&D AB (Järna, Sweden) and was milled to $<800 \mu \mathrm{m}$ particle size (Perten Laboratory Mill 120, Perten Instruments AB, Huddinge, Sweden). The nutrient content of oat bran was analysed by Eurofins Food and Agro AB (Lidköping, Sweden). Both meals contained $250 \mathrm{ml}$ blackcurrant beverage with pulp (Kiviks musteri AB, Kivik, Sweden), and in the test meal, $82 \mathrm{~g}$ oat bran was added to give $5 \mathrm{~g}$ soluble fibre (12.6 g total fibre). Rapeseed oil (Di Luca \& Di Luca AB, Stockholm, Sweden) was added to the control meal to balance the total amount of lipids, and dextrose powder (Dextro Energy GmbH \& Co. KG, Krefeld, Germany) and white bread (Lockarps bageri AB, Malmö, Sweden) was used to balance the amount of total carbohydrates. Both meals contained $75 \mathrm{~g}$ available carbohydrates and $8 \mathrm{~g}$ lipids (Table 1). Together with the beverage and the white bread, a glass of tap water $(200 \mathrm{ml})$ was served and the meals were ingested within $15 \mathrm{~min}$.

Blood sampling and biochemical analyses

Venous blood samples for gene expression profiling were taken before and $2 \mathrm{~h}$ after the meals for isolation of peripheral blood mononuclear cells (PBMCs) in $8 \mathrm{ml}$ sodium citrate tubes (Vacutainer CPT, Becton-Dickinson, Franklin Lakes, NJ, USA). The tubes were centrifuged (1800 g, $20 \mathrm{~min}$ at room temperature, Beckman GPR, Beckman Coulter Inc., Fullerton, CA, USA) within 2 h, and the cells were washed in autoclaved phosphate buffered saline (Gibco, Invitrogen Ltd, Paisley, UK). The PBMC pellet was dissolved in $1.2 \mathrm{ml}$ Trizol Reagent (Invitrogen) and immediately put in $\mathrm{a}-80^{\circ} \mathrm{C}$ freezer.

For the analysis of glucose, insulin and triglyceride concentrations, venous blood samples were collected before and every $30 \mathrm{~min}$ after the meal intake for $3 \mathrm{~h}$. Plasma glucose was immediately analysed (HemoCue AB, 
Table 1 Nutrient content of the two test meals

\begin{tabular}{|c|c|c|c|c|c|c|c|}
\hline & Amount (g) & Energy $(\mathrm{kJ})$ & Carbohydrate (g) & Lipids (g) & Protein $(\mathrm{g})$ & Soluble fibre $(\mathrm{g})$ & Total fibre $(\mathrm{g})$ \\
\hline \multicolumn{8}{|l|}{ Oat bran meal } \\
\hline Oat bran & 82.0 & 1190 & 36.8 & 7.5 & 17.0 & 5.0 & 12.6 \\
\hline Black currant beverage with pulp & 250.0 & 500 & 30.0 & - & - & - & - \\
\hline White bread & 15.5 & 175 & 8.2 & 0.4 & 1.2 & 0.0 & 0.3 \\
\hline Total (\% of total meal energy) & 347.5 & 1865 & $75.0(68)$ & $7.9(16)$ & $18.2(16)$ & 5.0 & 12.9 \\
\hline \multicolumn{8}{|l|}{ Control meal } \\
\hline Black currant beverage with pulp & 250.0 & 500 & 30.0 & - & - & - & - \\
\hline White bread & 67.7 & 768 & 35.9 & 2.0 & 5.4 & 0.3 & 1.4 \\
\hline Dextrose & 10.0 & 155 & 9.1 & - & - & - & - \\
\hline Rapeseed oil & 5.9 & 218 & - & 5.9 & - & - & - \\
\hline Total (\% of total meal energy) & 333.6 & 1641 & $75.0(77)$ & $7.9(18)$ & $5.4(5)$ & 0.3 & 1.4 \\
\hline
\end{tabular}

The data were calculated according to the declared nutrient content of each item, except for the oat bran that was analysed separately

Ängelholm, Sweden), while plasma samples for the determination of triglyceride concentration were stored in a refrigerator for up to 2 days until analysis at Lund University Hospital (Hitachi Modular-P4). Serum samples for measuring insulin concentration were stored at $-20^{\circ} \mathrm{C}$ until analysed (Mercodia AB, Uppsala, Sweden).

RNA isolation and hybridisation

The PBMC was stored in Trizol in a freezer for a maximum of 4 months. RNA was extracted from the cells according to the Trizol protocol and frozen. For further purification, the RNeasy MinElute Cleanup Kit (Qiagen, Basel, Switzerland) was used and the samples were immersed in liquid nitrogen and stored at $-80^{\circ} \mathrm{C}$. Samples from 5 men and 5 women were selected for the 40 microarray chips available (before and after oat bran and control meals). From the 15 subjects that completed the meals, two were excluded because of reported illness and one because of analytic problems (turbid sample). Samples from 12 subjects (6 men and 6 women) were checked for RNA degradation, quantification and purity by gel electrophoresis (E-gel PowerBase, Invitrogen) and a nanodrop spectrophotometer (ND-1000, NanoDrop Technologies, Wilmington, DE, USA). Samples from five subjects from each gender with the best RNA quality and quantity were selected and processed at the SCIBLU Swegene Centre for Integrative Biology (Lund University) according to the Affymetrix One-Cycle protocol Technical Manual 701025 rev6 (Santa Clara, CA, USA). At the SCIBLU centre, RNA quality and quantity was determined using Agilent RNA 6000 Nano Kit in conjunction with Agilent 2100 Bioanalyzer (Agilent Technologies, Santa Clara, CA, USA).

A total of $1.7 \mu \mathrm{g}$ RNA was used from the samples to generate biotin-labelled antisense cRNA, which was used for hybridisation to the NuGO Affymetrix Human Gene chip NuGO_Hs1a520180 (custom design by the European Nutrigenomics Organisation (NuGO) including 23941 probe sets, whereof 71 were control probe sets, ArrayExpress accession number A-AFFY-111, http://www.ebi.ac. uk/arrayexpress) according to the manufacturer's instruction. The samples were divided into 4 hybridisation batches, with samples from each individual remaining in the same batch. Absolute values of expression were calculated from the scanned arrays using GeneChip Operating Software 1.4. Microarray data are available in the ArrayExpress database under accession number E-MEXP-2261.

\section{Data analysis}

Expression levels of probe sets were summarised using the gene chip robust multiarray average algorithm, GCRMA (Wu et al. 2004). Expression data was logtransformed (base 2). A principal component analysis (PCA) plot was performed to identify any separation between samples.

We employed two linear mixed models. The first model 'Meal Intake Model' determined the effect of meal intake, compared to before meal intake, and was employed for the oat bran meal and control meal data separately. The Meal Intake Model had log gene expression as a response, gender and meal intake as fixed effects and individuals as random effect. The second model 'Meal Content Model' was employed to find the specific effect resulting from the oat bran meal, relative to the control meal. The Meal Content Model had log gene expression as a response, gender, meal intake and meal content as fixed effects, and the interaction of individual and the week in which the subjects ate oat bran as a random effect. The random effect variable was included to account for a temporal shift in the gene expression of an individual. Linear mixed models were used through the lme function within the nlme 
package in $\mathrm{R}$ 2.8.0/Bioconductor ( $\mathrm{R}$ Development Core Team 2008; Gentleman et al. 2004). A custom annotation file for the NuGO_Hs1a520180 chip was used (version from Oct 2008; http://www.bigcat.unimaas.nl/ martijn/ NuGO/annotations/), and a conversion table to other annotations for all genes can be found in Online Resource 1. Gene Ontology descriptions for single genes were received from NetAffx Analysis Centre (http://www. affymetrix.com). Overrepresentation of gene sets with a common biological function correlated with meal intake and oat bran intake, specifically, was determined using the software program Gene Set Enrichment Analysis, GSEA (Subramanian et al. 2005; Mootha et al. 2003). All 23941 genes were ranked, in decreasing order, by their fold changes as a response to either meal intake or oat bran intake, from the Meal Content Model. GSEA determines the degree to which a gene set is overrepresented at the top or the bottom of the ranked list. All 3200 gene sets from the Molecular Signature Database c2 v 3.0 were included, consisting of curated gene sets from various sources, such as online databases and publications in PubMed.

The threshold for significance was set at a $t$ test $P$-value $<0.01$ for differentially expressed genes, and the false discovery rate (FDR) method was used to correct for multiple testing (Benjamini and Hochberg 1995). The calculated FDR indicates the expected proportion of false positives in the list of differentially expressed genes. For gene sets from GSEA, a FDR q-value $<0.01$ was set as a threshold for enriched gene sets.

Statistical analyses of postprandial glucose and triglyceride concentrations were performed on the 15 subjects (8 men and 7 women) who completed the meals with high compliance, while postprandial insulin concentration was missing for two subjects. Wilcoxon signed rank test was used for nonparametric pair wise evaluations, using SPSS 16.0 (SPSS Inc., Chicago, IL, USA). A $P$-value of $<0.05$ was considered significant in the analyses of postprandial glucose, insulin and triglycerides.

\section{Results}

Fifteen ( 8 men and 7 women) of eighteen study subjects completed the meals, two dropped out for personal reasons, and one was excluded due to low compliance. The 15 subjects were between 20 and 28 years of age with a mean BMI of $22.8 \mathrm{~kg} / \mathrm{m}^{2}$ (standard deviation, $\mathrm{SD}=2.1$ ). Mean baseline characteristics indicated a glucose concentration of $5.2 \mathrm{mmol} / \mathrm{l} \quad(\mathrm{SD}=0.2)$, insulin concentration of $5.5 \mathrm{mU} / \mathrm{l}(\mathrm{SD}=1.4)$ and triglyceride concentration of $1.2 \mathrm{mmol} / \mathrm{l}(\mathrm{SD}=0.4)$. The five men and five women selected for the microarray gene expression profiling had a mean BMI of 23.2 and $21.9 \mathrm{~kg} / \mathrm{m}^{2}$, respectively.
All RNA samples isolated from the PBMCs had a high RNA quality (RNA integrity number $(\mathrm{RIN})>8.0$; maximum 10) and all arrays passed the quality control (NuGO MadMax pipeline, Wageningen, The Netherlands, https://madmax.bioinformatics.nl) and were used for normalisation. The PCA plot showed clustering of the four samples from the same individual and separation between genders, but not between treatments (Fig. 1).

The application of the Meal Intake Model, which analyses the meals separately, on the oat bran meal data resulted in a gene list containing 1877 differentially expressed genes as a response to meal intake $(P<0.01$, FDR $=0.13)$. The same model applied to the control meal gave a list of 848 differentially expressed genes as a response to meal intake $(P<0.01$, FDR $=0.28)$. Within these two lists, 287 of the genes were the same after both oat bran and control meal intake. The genes which were most highly regulated were up- or down-regulated in the same direction after both meals (Table 2). Among these, the gene PDK4 inhibits the activity of pyruvate dehydrogenase that catalyses an irreversible step in glucose oxidation (Berg et al. 2006; Rowles et al. 1996), while DDIT4 (also known as REDD1) inhibits the mammalian target of rapamycin pathway and hence the protein synthesis (Sofer et al. 2005). Down-regulation of these genes suggests active glucose oxidation and protein synthesis as a response to the two meals. The genes GPR34, DEFA3 and EGR1 are all related to inflammation (Makide et al. 2009; Visvikis-Siest et al. 2007; Aljada et al. 2004), and upregulation of these genes after both meals indicates that some extracellular signals reaching the PBMCs triggered the immune system.

The Meal Content Model, isolating the specific effects of the oat bran, resulted in a gene list with 218 differentially regulated genes $(P<0.01, \mathrm{FDR}=1$, the high FDR indicates that all genes could be false positives). The genes with the highest differential expression are shown in Table 3. The most down-regulated genes are related to processes like transcriptional regulation (USP53, ID3), cell communication (NOG, PKIA) and the T-cell receptor (TRBV5-1), while the most up-regulated ones are related to signal transduction (SIRPB1, MRVI1), immune response (IL18), metabolic processes (GSTM2) and transcriptional regulation (ZNF24, SMARCC2). The whole gene list from the Meal Content Model is given in Online Resource 2.

Gene set enrichment analysis, measuring the overrepresentation of gene sets in a gene list, was performed on the ranked fold changes from the Meal Content Model for all genes, as a response to meal intake as well as oat bran intake specifically. As a response to meal intake, irrespective of meal content, 24 gene sets were significantly enriched for down-regulated genes, as were 192 gene sets for up-regulated genes $(P<0.01$, FDR $<0.01)$. The most 


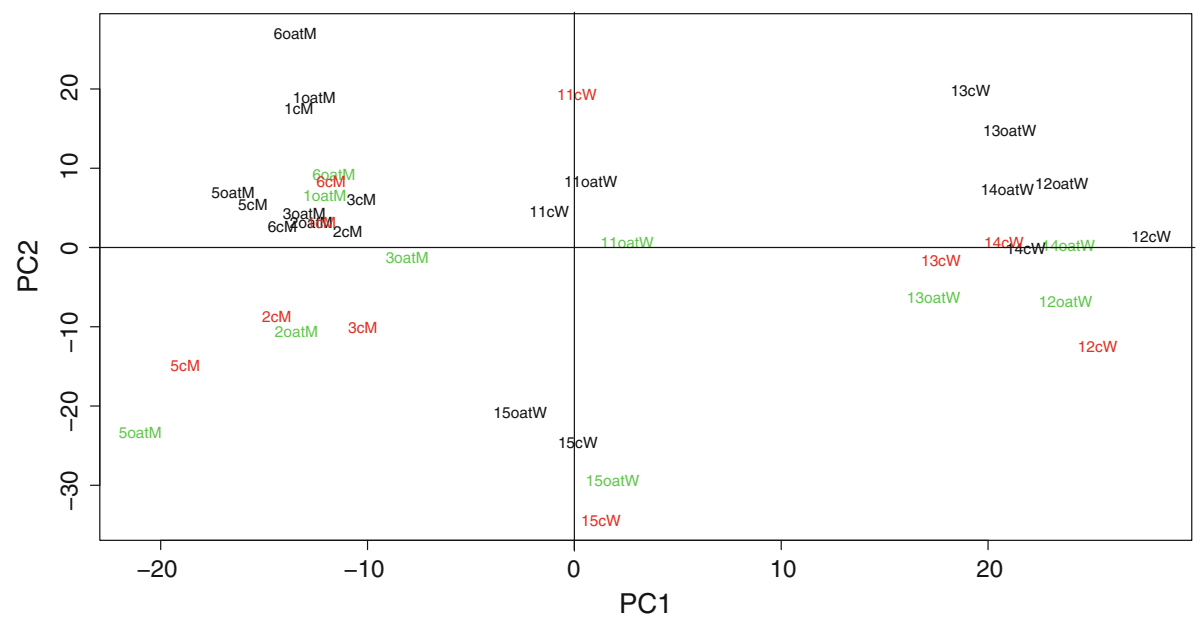

Fig. 1 Principal component plot of samples indicating that women clustered into two groups, while men clustered in one, and the effects due to gender and individual differences were much larger than those due to the meal intake and oat bran intake. The digits represent subject identification number (men 1-3, 5-6 and women 11-15), 'oat' represents the occasion when the oat bran meal was eaten, and 'c' the occasion when the control meal was eaten, ' $M$ ' represents man and ' $W$ ' woman. Green colour represents $2 \mathrm{~h}$ after oat bran intake and red colour represents $2 \mathrm{~h}$ after control intake. $\mathrm{X}$ - and $\mathrm{Y}$-axes represent the 1 st and 2nd principal components, respectively

Table 2 The 16 most differentially expressed genes $(P<0.01)$ after oat bran or control meal intake (compared to before intake), as analysed by the Meal Intake Model

\begin{tabular}{|c|c|c|c|c|c|c|c|c|}
\hline \multirow[t]{2}{*}{ Gene name } & \multirow[t]{2}{*}{ Probe set identifier } & \multirow{2}{*}{$\begin{array}{l}\text { Gene } \\
\text { symbol }\end{array}$} & \multicolumn{3}{|c|}{ Oat bran meal } & \multicolumn{3}{|c|}{ Control meal } \\
\hline & & & $\begin{array}{l}\text { Fold } \\
\text { change }\end{array}$ & SEM & $P$-value & $\begin{array}{l}\text { Fold } \\
\text { change }\end{array}$ & SEM & $P$-value \\
\hline \multicolumn{9}{|l|}{ Down-regulated } \\
\hline Pyruvat dehydrogenase kinase, isozyme 4 & 225207_at & PDK4 & 0.27 & 0.07 & 0.0005 & 0.22 & 0.04 & $<0.0001$ \\
\hline DNA-damage-inducible transcript 4 & 202887_s_at & DDIT4 & 0.53 & 0.05 & 0.0001 & 0.45 & 0.05 & 0.0001 \\
\hline $\begin{array}{l}\text { Transmembrane protein with EGF-like and two } \\
\text { follistatin-like domains } 2\end{array}$ & 224321_at & TMEFF2 & 0.54 & 0.06 & 0.0005 & 0.85 & 0.07 & 0.0955 \\
\hline $\begin{array}{l}\text { Solute carrier family } 16, \text { member } 10 \text { (aromatic amino } \\
\text { acid transporter) }\end{array}$ & 219915_s_at & SLC16A10 & 0.59 & 0.07 & 0.0014 & 0.85 & 0.09 & 0.1543 \\
\hline Desmocollin 1 & NuGO_eht0257197_at & DSC1 & 0.59 & 0.04 & 0.0001 & 0.77 & 0.08 & 0.0269 \\
\hline Aldo-keto reductase family 1 , member $\mathrm{C} 3$ & 209160_at & AKR1C3 & 0.62 & 0.08 & 0.0063 & 0.56 & 0.05 & 0.0002 \\
\hline Chemokine (C-C motif) ligand 4 & 204103_at & CCL4 & 0.72 & 0.06 & 0.0033 & 0.56 & 0.03 & $<0.0001$ \\
\hline Fasciculation and elongation protein zeta 1 (zygin I) & 203562_at & FEZ1 & 0.73 & 0.07 & 0.0105 & 0.55 & 0.05 & 0.0002 \\
\hline \multicolumn{9}{|c|}{ Up-regulated } \\
\hline Early growth response protein 1 & 201694_s_at & EGR1 & 3.08 & 0.92 & 0.0046 & 2.37 & 1.36 & 0.1698 \\
\hline Neutrophil defensin 3 precursor & 205033_s_at & DEFA3 & 2.07 & 1.16 & 0.2260 & 2.36 & 0.52 & 0.0036 \\
\hline Chemokine (C-X-C motif) ligand 16 & 223454_at & CXCL16 & 1.99 & 0.24 & 0.0003 & 1.44 & 0.15 & 0.0060 \\
\hline $\begin{array}{l}\text { Cysteine-rich secretory protein LCCL domain } \\
\text { containing } 2\end{array}$ & 221541_at & CRISPLD2 & 1.95 & 0.14 & $<0.0001$ & 1.79 & 0.20 & 0.0006 \\
\hline Carboxypeptidase M & 206100_at & CPM & 1.95 & 0.27 & 0.0010 & 1.23 & 0.14 & 0.0969 \\
\hline Caldesmon 1 & 212077_at & CALD1 & 1.91 & 0.16 & $<0.0001$ & 1.27 & 0.10 & 0.0127 \\
\hline Lipocalin 2 & 212531_at & $\mathrm{LCN} 2$ & 1.80 & 0.19 & 0.0004 & 1.80 & 0.28 & 0.0040 \\
\hline G protein-coupled receptor 34 & 223620_at & GPR34 & 1.75 & 0.24 & 0.0024 & 2.08 & 0.12 & $<0.0001$ \\
\hline
\end{tabular}

Fold change and $P$-value for the other meal is shown for comparison. The genes are sorted according to fold change by the oat bran meal. (Mean values with their standard errors, $n=10$ ) 
Table 3 The 16 most differentially expressed genes of the total 218 differentially expressed genes $(P<0.01)$ after the oat bran meal, compared with the control meal, as analysed by the Meal Content Model. (Mean values with their standard errors, $n=10$ )

\begin{tabular}{|c|c|c|c|c|c|}
\hline Gene name & Probe set identifier & Gene symbol & Fold change & SEM & $P$-value \\
\hline \multicolumn{6}{|l|}{ Down-regulated } \\
\hline Ubiquitin-specific peptidase 5 & 230083_at & USP53 & 0.62 & 0.05 & $<0.0001$ \\
\hline $\begin{array}{l}\text { Inhibitor of DNA binding 3, dominant negative } \\
\text { helix-loop-helix protein }\end{array}$ & 207826_s_at & ID3 & 0.66 & 0.05 & 0.0001 \\
\hline Noggin precursor & 231798_at & NOG & 0.67 & 0.06 & 0.0006 \\
\hline Hypothetical LOC29092 similar to HSPC157 & 219865_at & AL031281.6 & 0.68 & 0.07 & 0.0022 \\
\hline Uncharacterized protein C4orf 16 & 219023_at & C4orf16 & 0.71 & 0.08 & 0.0065 \\
\hline $\mathrm{T}$-cell receptor beta $\mathrm{V}$ gene segment & NuGO_eht0356506_x_at & TRBV5-1 & 0.74 & 0.05 & 0.0005 \\
\hline cAMP-dependent protein kinase inhibitor alpha & 204612_at & PKIA & 0.75 & 0.06 & 0.0031 \\
\hline IL-4-R mRNA for the interleukin 4 receptor & 242743_at & IL4R & 0.76 & 0.06 & 0.0031 \\
\hline \multicolumn{6}{|l|}{ Up-regulated } \\
\hline Signal-regulatory protein beta 1 & 206934_at & SIRPB1 & 1.51 & 0.13 & 0.0001 \\
\hline Caldesmon 1 & 212077_at & CALD1 & 1.49 & 0.17 & 0.0024 \\
\hline Protein MRVI1 & 230214_at & MRVI1 & 1.47 & 0.14 & 0.0006 \\
\hline Interleukin-18 precursor (IL-18) & 206295_at & IL18 & 1.46 & 0.17 & 0.0050 \\
\hline Truncated zinc finger protein isoform & 242210_at & ZNF24 & 1.41 & 0.15 & 0.0055 \\
\hline SWI/SNF complex $170 \mathrm{KDa}$ subunit (BAF170) & 1561973_at & SMARCC2 & 1.39 & 0.16 & 0.0089 \\
\hline Ring finger protein, transmembrane 1 & 221195_at & RNFT1 & 1.38 & 0.12 & 0.0024 \\
\hline Glutathione S-transferase Mu 2 & 204418_x_at & GSTM2 & 1.38 & 0.14 & 0.0069 \\
\hline
\end{tabular}

significantly affected gene sets are shown in Table 4, while Online Resource 3 contains all significantly influenced gene sets. The most down-regulated gene sets comprised pathways related to transcription and coding/synthesis of insulin (Table 4). Many of the 192 up-regulated gene sets were related to cancer diseases. Additionally, several were associated with inflammatory responses (FULCHER INFLAMMATORY RESPONSE LECTIN VS LPS DN, FULCHER INFLAMMATORY RESPONSE LECTIN VS LPS UP, FOSTER INFLAMMATORY RESPONSE LPS DN, FOSTER INFLAMMATORY RESPONSE LPS UP, REACTOME SIGNALING IN IMMUNE SYSTEM) and gluconeogenesis (KEGG GLYCOLYSIS GLUCONEOGENESIS, MOOTHA GLUCONEOGENESIS).

GSEA of the specific response to oat bran (corrected for meal intake) indicated that 15 gene sets were significantly enriched for down-regulated genes and 28 gene sets for upregulated genes $(P<0.01, \mathrm{FDR}<0.01$, Table 5$)$. The list of gene sets demonstrate which of the gene sets regulated by the meal intake that were regulated due to specific effects of oat bran. The down-regulated gene sets were associated with $\beta$-cells and coding/synthesis of insulin (REACTOME INSULIN SYNTHESIS AND SECRETION REACTOME REGULATION OF BETA CELL DEVELOPMENT, REACTOME REGULATION OF GENE EXPRESSION IN BETA CELLS), ribosomal and translational pathways (KEGG RIBOSOME, REACTOME PEPTIDE CHAIN ELONGATION, REACTOME TRANS-
LATION) and viral transcription and translation (REACTOME INFLUENZA LIFE CYCLE, REACTOME INFLUENZA VIRAL RNA TRANSCRIPTION AND REPLICATION). Many of the up-regulated and some of the down-regulated gene sets that were regulated as a response to the oat bran meal were associated with cancer diseases (Table 5).

The postprandial glucose, insulin and triglyceride concentrations are presented in Table 6. Postprandial glucose concentrations after the oat bran meal were lower than those after the control meal, although not significantly. Postprandial insulin concentrations were significantly lower at $60 \mathrm{~min}(P=0.008)$ and significantly higher at 180 min $(P=0.003)$ after the oat bran meal compared with the control meal. The insulin incremental area under the curve (IAUC) was significantly lower for the oat bran meal using a 0-90 min interval $(P=0.021)$ and a $0-120 \mathrm{~min}$ interval $(P=0.048)$. The postprandial triglyceride concentration tended to be higher after the oat bran meal compared with the control meal, although not significantly.

\section{Discussion}

The oat bran meal resulted in a higher number of differentially expressed genes compared with the control meal. Although this suggests that the oat bran meal has a larger 
Table 4 The 30 most significantly affected gene sets as a response to meal intake (after meal compared with before meal) of the total of 24 significantly down-regulated and 192 significantly up-regulated gene sets $(P<0.01$, FDR q $<0.01)$ analysed with GSEA

\begin{tabular}{|c|c|c|}
\hline Gene sets & FDR q-value & Gene set size \\
\hline \multicolumn{3}{|l|}{ Down-regulated } \\
\hline REACTOME_REGULATION_OF_GENE_EXPRESSION_IN_BETA_CELLS & $<0.0001$ & 78 \\
\hline KEGG_RIBOSOME & $<0.0001$ & 75 \\
\hline REACTOME_FORMATION_OF_A_POOL_OF_FREE_40S_SUBUNITS & $<0.0001$ & 73 \\
\hline REACTOME_VIRAL_MRNA_TRANSLATION & $<0.0001$ & 73 \\
\hline REACTOME_GTP_HYDROLYSIS_AND_JOINING_OF_THE_60S_RIBOSOMAL_SUBUNIT & $<0.0001$ & 82 \\
\hline REACTOME_REGULATION_OF_BETA_CELL_DEVELOPMENT & $<0.0001$ & 83 \\
\hline REACTOME_PEPTIDE_CHAIN_ELONGATION & $<0.0001$ & 74 \\
\hline HAHTOLA_SEZARY_SYNDROM_DN & $<0.0001$ & 34 \\
\hline HAHTOLA_MYCOSIS_FUNGOIDES_CD4_DN & $<0.0001$ & 97 \\
\hline REACTOME_INFLUENZA_VIRAL_RNA_TRANSCRIPTION_AND_REPLICATION & $<0.0001$ & 88 \\
\hline REACTOME_INFLUENZA_LIFE_CYCLE & $<0.0001$ & 120 \\
\hline REACTOME_TRANSLATION & $<0.0001$ & 95 \\
\hline REACTOME_GENE_EXPRESSION & $<0.0001$ & 329 \\
\hline JISON_SICKLE_CELL_DISEASE_DN & $<0.0001$ & 145 \\
\hline REACTOME_INSULIN_SYNTHESIS_AND_SECRETION & $<0.0001$ & 110 \\
\hline \multicolumn{3}{|l|}{ Up-regulated } \\
\hline VERHAAK_AML_WITH_NPM1_MUTATED_UP & $<0.0001$ & 159 \\
\hline RUTELLA_RESPONSE_TO_CSF2RB_AND_IL4_DN & $<0.0001$ & 272 \\
\hline JAATINEN_HEMATOPOIETIC_STEM_CELL_DN & $<0.0001$ & 193 \\
\hline RAGHAVACHARI_PLATELET_SPECIFIC_GENES & $<0.0001$ & 62 \\
\hline MCLACHLAN_DENTAL_CARIES_UP & $<0.0001$ & 187 \\
\hline TAKEDA_TARGETS_OF_NUP98_HOXA9_FUSION_8D_DN & $<0.0001$ & 163 \\
\hline RUTELLA_RESPONSE_TO_HGF_VS_CSF2RB_AND_IL4_UP & $<0.0001$ & 347 \\
\hline SMIRNOV_CIRCULATING_ENDOTHELIOCYTES_IN_CANCER_UP & $<0.0001$ & 141 \\
\hline JISON_SICKLE_CELL_DISEASE_UP & $<0.0001$ & 161 \\
\hline MCLACHLAN_DENTAL_CARIES_DN & $<0.0001$ & 210 \\
\hline HAHTOLA_MYCOSIS_FUNGOIDES_CD4_UP & $<0.0001$ & 58 \\
\hline VALK_AML_CLUSTER_5 & $<0.0001$ & 27 \\
\hline FULCHER_INFLAMMATORY_RESPONSE_LECTIN_VS_LPS_DN & $<0.0001$ & 372 \\
\hline GAL_LEUKEMIC_STEM_CELL_DN & $<0.0001$ & 207 \\
\hline HESS_TARGETS_OF_HOXA9_AND_MEIS1_DN & $<0.0001$ & 63 \\
\hline
\end{tabular}

GSEA gene set enrichment analysis

metabolic effect than the control meal, the difference in number of differentially expressed genes must be interpreted with caution, since it neither reveals the magnitude of regulation nor the identity of the genes. It is more important to identify, and individually study, the differentially expressed genes (Table 2). The general meal intake effects on gene expression, regardless of nutrient content, appear to be related to increased metabolic stress and inflammation. In line with our results, several of the highly regulated genes were also found to be changed after meal intake in other studies. For example, a meal study found a down-regulation of the gene DDIT4 after meal intake, and its relevance was discussed as a biomarker for feeding (van
Erk et al. 2006). This gene was also found to be up-regulated by food deprivation and after induction of type-1 diabetes in rats (McGhee et al. 2009). The most up-regulated gene in the present study, EGR1, activates the transcription of genes, such as tissue factor (TF), tumour necrosis factor (TNF)- $\alpha$ and interleukin (IL)-2. In other studies, this gene was reported to be increased by glucose intake and suppressed by insulin (Aljada et al. 2002; Aljada et al. 2004). The GSEA also indicated activated inflammation as a response to the intake of both meals.

When using the Meal Content Model for isolation of the specific effect of oat bran, the statistical analysis resulted in a gene list with 218 differentially expressed genes, all of 
Table 5 All gene sets affected as a response to the oat bran meal compared with the control meal $(P<0.01$, FDR q $<0.01)$ analysed with GSEA

\begin{tabular}{|c|c|c|}
\hline Gene sets & FDR q-value & Gene set size \\
\hline \multicolumn{3}{|l|}{ Down-regulated } \\
\hline REACTOME_GTP_HYDROLYSIS_AND_JOINING_OF_THE_60S_RIBOSOMAL_SUBUNIT & 0.0008 & 82 \\
\hline REACTOME_FORMATION_OF_A_POOL_OF_FREE_40S_SUBUNITS & 0.0004 & 73 \\
\hline KEGG_RIBOSOME & 0.0003 & 75 \\
\hline REACTOME_REGULATION_OF_BETA_CELL_DEVELOPMENT & 0.0002 & 83 \\
\hline REACTOME_PEPTIDE_CHAIN_ELONGATION & 0.0002 & 74 \\
\hline REACTOME_VIRAL_MRNA_TRANSLATION & 0.0001 & 73 \\
\hline REACTOME_REGULATION_OF_GENE_EXPRESSION_IN_BETA_CELLS & 0.0001 & 78 \\
\hline REACTOME_INFLUENZA_VIRAL_RNA_TRANSCRIPTION_AND_REPLICATION & 0.0003 & 88 \\
\hline REACTOME_TRANSLATION & 0.0004 & 95 \\
\hline REACTOME_INFLUENZA_LIFE_CYCLE & 0.0028 & 120 \\
\hline REACTOME_INSULIN_SYNTHESIS_AND_SECRETION & 0.0043 & 110 \\
\hline WINNEPENNINCKX_MELANOMA_METASTASIS_UP & 0.0050 & 128 \\
\hline HUTTMANN_B_CLL_POOR_SURVIVAL_DN & 0.0050 & 51 \\
\hline PUJANA_BRCA2_PCC_NETWORK & 0.0061 & 368 \\
\hline PUJANA_XPRSS_INT_NETWORK & 0.0084 & 151 \\
\hline \multicolumn{3}{|l|}{ Up-regulated } \\
\hline VERHAAK_AML_WITH_NPM1_MUTATED_UP & $<0.0001$ & 159 \\
\hline HUTTMANN_B_CLL_POOR_SURVIVAL_UP & $<0.0001$ & 243 \\
\hline RAGHAVACHARI_PLATELET_SPECIFIC_GENES & $<0.0001$ & 62 \\
\hline HSIAO_HOUSEKEEPING_GENES & $<0.0001$ & 346 \\
\hline MULLIGHAN_MLL_SIGNATURE_2_UP & $<0.0001$ & 361 \\
\hline RICKMAN_METASTASIS_DN & $<0.0001$ & 219 \\
\hline RUTELLA_RESPONSE_TO_CSF2RB_AND_IL4_DN & 0.0002 & 272 \\
\hline REACTOME_RNA_POLYMERASE_I_PROMOTER_OPENING & 0.0001 & 28 \\
\hline JAATINEN_HEMATOPOIETIC_STEM_CELL_DN & 0.0001 & 193 \\
\hline MULLIGHAN_MLL_SIGNATURE_1_UP & 0.0001 & 330 \\
\hline SCHUETZ_BREAST_CANCER_DUCTAL_INVASIVE_UP & 0.0005 & 306 \\
\hline RUTELLA_RESPONSE_TO_HGF_VS_CSF2RB_AND_IL4_UP & 0.0016 & 347 \\
\hline ROSS_AML_WITH_AML1_ETO_FUSION & 0.0025 & 65 \\
\hline SMIRNOV_CIRCULATING_ENDOTHELIOCYTES_IN_CANCER_UP & 0.0025 & 141 \\
\hline TONKS_TARGETS_OF_RUNX1_RUNX1T1_FUSION_HSC_DN & 0.0023 & 167 \\
\hline HOSHIDA_LIVER_CANCER_SUBCLASS_S1 & 0.0023 & 212 \\
\hline JAATINEN_HEMATOPOIETIC_STEM_CELL_UP & 0.0025 & 257 \\
\hline RODWELL_AGING_KIDNEY_UP & 0.0025 & 284 \\
\hline HELLER_HDAC_TARGETS_UP & 0.0036 & 245 \\
\hline JISON_SICKLE_CELL_DISEASE_UP & 0.0035 & 161 \\
\hline RUTELLA_RESPONSE_TO_HGF_DN & 0.0037 & 206 \\
\hline OSMAN_BLADDER_CANCER_UP & 0.0044 & 330 \\
\hline MCLACHLAN_DENTAL_CARIES_UP & 0.0054 & 187 \\
\hline YANAGIHARA_ESX1_TARGETS & 0.0068 & 19 \\
\hline DELYS_THYROID_CANCER_UP & 0.0067 & 354 \\
\hline REN_ALVEOLAR_RHABDOMYOSARCOMA_DN & 0.0067 & 381 \\
\hline THUM_SYSTOLIC_HEART_FAILURE_UP & 0.0075 & 345 \\
\hline WIELAND_UP_BY_HBV_INFECTION & 0.0077 & 91 \\
\hline
\end{tabular}

GSEA gene set enrichment analysis 
Table 6 Fasting and incremental glucose, insulin and triglyceride concentrations at 30, 60, 120 and 180 min and glucose and insulin incremental area under the curve (IAUC) in healthy humans after the intake of oat bran meal and control meal. (Mean values with their standard errors, glucose/triglycerides $n=15$; insulin $n=13$ )

\begin{tabular}{|c|c|c|c|c|c|c|c|c|c|c|c|c|c|c|c|c|}
\hline & \multirow{2}{*}{\multicolumn{2}{|c|}{$\begin{array}{l}\text { Fasting } \\
\text { concentration }\end{array}$}} & \multirow{2}{*}{\multicolumn{2}{|c|}{$\Delta 30 \min$}} & \multirow{2}{*}{\multicolumn{2}{|c|}{$\Delta 60 \min$}} & \multirow{2}{*}{\multicolumn{2}{|c|}{$\Delta 120 \mathrm{~min}$}} & \multirow{2}{*}{\multicolumn{2}{|c|}{$\Delta 180 \mathrm{~min}$}} & \multicolumn{6}{|l|}{ IAUC } \\
\hline & & & & & & & & & & & \multicolumn{2}{|c|}{$0-60 \mathrm{~min}$} & \multicolumn{2}{|c|}{ 0-90 min } & \multicolumn{2}{|c|}{$0-120 \mathrm{~min}$} \\
\hline & Mean & SEM & Mean & SEM & Mean & SEM & Mean & SEM & Mean & SEM & Mean & SEM & Mean & SEM & Mean & SEM \\
\hline Glucose (mmol/l) & & & & & & & & & & & & & $\mathrm{mmol}$ & $\min / 1$ & & \\
\hline Control & 5.2 & 0.1 & 2.8 & 0.3 & 1.0 & 0.4 & -0.3 & 0.3 & -0.2 & 0.2 & 109.5 & 12.7 & 136.9 & 19.3 & 150.2 & 23.1 \\
\hline Oat bran & 5.2 & 0.1 & 2.3 & 0.2 & 0.7 & 0.2 & 0.3 & 0.1 & 0.3 & 0.2 & 81.2 & 7.9 & 99.1 & 12.7 & 110.3 & 15.9 \\
\hline Insulin (mU/l) & & & & & & & & & & & & & $\mathrm{mU} \mathrm{m}$ & in/l & & \\
\hline Control & 5.7 & 0.4 & 39.0 & 5.4 & 34.2 & 5.2 & 11.3 & 3.6 & 1.5 & 1.1 & 1683 & 201 & 2458 & 309 & 2890 & 402 \\
\hline Oat bran & 5.3 & 0.6 & 36.2 & 5.4 & $20.5^{\mathrm{a}}$ & 2.3 & 12.1 & 2.4 & $5.0^{\mathrm{a}}$ & 1.1 & 1395 & 176 & $1874^{\mathrm{b}}$ & 213 & $2227^{\mathrm{b}}$ & 255 \\
\hline \multicolumn{17}{|c|}{ Triglycerides $(\mathrm{mmol} / \mathrm{l})$} \\
\hline Control & 1.12 & 0.11 & -0.07 & 0.02 & -0.08 & 0.03 & -0.13 & 0.03 & -0.12 & 0.04 & nd & & nd & & nd & \\
\hline Oat bran & 1.18 & 0.13 & -0.08 & 0.03 & -0.04 & 0.03 & -0.03 & 0.06 & -0.05 & 0.07 & nd & & nd & & nd & \\
\hline
\end{tabular}

IAUC incremental area under the curve

${ }^{\mathrm{a}}$ Wilcoxon signed rank test; significantly different compared to control $(P<0.01)$

b Wilcoxon signed rank test; significantly different compared to control $(P<0.05)$

which may be false positives, i.e. lacking statistical significance. However, even without demonstrating any significance for the single genes, it was possible to find statistical significance for regulated groups of genes by using GSEA (Table 5). The oat bran meal suppressed genes and pathways associated with insulin (lower $\beta$-cell development and lower expression/secretion of insulin), compared with the control meal. Less need of insulin may lead to lower $\beta$-cell production, as the $\beta$-cell mass is dynamic and increases or decreases in mass and function as a response to the glycemic level, see e.g. Bonner-Weir et al. (2010). The lower need of insulin after the oat bran meal consequently resulted in decreased insulin concentrations in the blood, as detected by the significantly reduced insulin IAUC after intake of the oat bran meal, compared with the control meal (Table 6).

Suppression of insulin levels after oat bran meals has been demonstrated previously, for example in studies by Juvonen et al. (2009) and Hallfrisch et al. (2003). This effect can be attributed to the high content of soluble dietary fibre in oat bran, mainly $\beta$-glucans, as these contribute to increased viscosity in the gastrointestinal tract and can reduce or delay macronutrient absorption. The dose of about $5 \mathrm{~g} \beta$-glucans in the oat bran meal was similar to the dose of $4-5 \mathrm{~g}$, which has previously been reported to normalise postprandial glucose and insulin concentrations (Granfeldt et al. 2008; Biörklund et al. 2005). Oat bran is also rich in phenolic acids (antioxidants), which may improve insulin responsiveness
(Caballero 1993), although a recent review indicates varying results (Tiganis 2010).

The lower insulin levels after the oat bran meal probably resulted in lower protein synthesis, as indicated by suppression of gene sets related to transcription of rDNA and translation of mRNA. The gene sets related to viral response are probably also reflecting a general down-regulated transcription and translation. Our discovery of effects in gene sets related to cancer diseases may also be related to the insulin levels. Insulin serves as a cell growth factor and can increase the levels of oestrogen and other tumour promoters as well as activate receptors that are highly expressed in malignant cells, e.g. the insulin receptor or the insulin-like growth factor-1 receptor (Boyd 2003). In the present study, it was not possible to determine the direction of regulation in cancer-related genes, since different gene sets were both suppressed and activated by the oat bran meal. A recent study with prostate cancer patients show that a 2 week diet rich in whole grain rye and bran decreased the insulin levels compared to a diet rich in refined wheat (Landberg et al. 2010). The decreased exposure to insulin was further suggested to cause a reduction in the prostate-specific antigen concentration and hence the progression of the cancer. Rye bran fibre was suggested to be responsible for the increased production of SCFA in the patients and was hence suggested to lead to activation of hepatic AMP-activated protein kinase, lower insulin secretion and reductive effects on cancer progression. 
Our observations that the most affected functional gene sets in PBMCs after a single oat bran-rich meal were related to the suppression of insulin pathways, and furthermore that other pathways related to insulin levels, such as protein synthesis and cancer diseases, were influenced, appear to be new findings. One long-term study, including subjects with the metabolic syndrome, reported that rye bread significantly lowered postprandial insulin concentrations compared with oat-wheat bread (Kallio et al. 2007). The same study also assessed gene expression in adipose tissue after a rye pasta diet, demonstrating that intake during 12 weeks resulted in down-regulation of genes related to insulin signalling. The effects of dietary fibre-rich fractions need to be confirmed by further studies, including the correlation of a single meal to a long-term intake as well as the effects mediated to different tissues.

The optimal time point for studying effects on gene expression after a meal is not firmly established. Blood samples were drawn at $2 \mathrm{~h}$ after the meals, since our focus was on the early effects of meal intake, and furthermore, in order to make the study comparable with a protein-carbohydrate intake study (van Erk et al. 2006). PBMCs were used, since it is an easily available source of RNA in human trials, and expression profiles from PBMC are stable within subjects (Eady et al. 2005). Blood cells interact with every organ and tissue in the body and convey bioactive molecules such as nutrients, metabolites and cytokines. PBMCs are involved in diseases like diabetes and cardiovascular diseases, and nutritional interventions have been shown to affect the transcriptome of these cells (Mohr and Liew 2007; de Roos 2009). We included both men and women in the study, since gender differences were found in a previous study of ours, where women showed a lower incremental glucose peak and IAUC after intake of fibrerich meals compared with men (Ulmius et al. 2009). As demonstrated by PCA (Fig. 1), the women clustered into two groups, while men clustered in one, and the effects due to gender and individual differences were much larger than those due to the meal intake and oat bran intake. Therefore, gender and individual differences had to be corrected for in the linear mixed models. We also tested for interactions between gender and fibre meal intake for any gene but found no such connections.

In conclusion, our pilot study demonstrated that a single meal rich in oat bran significantly lowered postprandial blood insulin IAUC and influenced the gene expression profile in PBMCs, $2 \mathrm{~h}$ after meal intake in healthy subjects, suppressing gene sets associated with the insulin level.

Acknowledgments This work was supported by the European Network of Excellence NuGO (The European Nutrigenomics Organisation), the Nordic Centre of Excellence in Systems biology in controlled dietary interventions and cohort studies (SYSDIET) and a VINNOVA grant (project number 2004-02285). The authors declare no conflict of interest. We gratefully thank RN Ingrid Palmquist for performing the blood sampling, SCIBLU Swegene Centre for Integrative Biology at Lund University for microarray measurements and $\mathrm{PhD}$ Vasileios Pagmantidis for help and support during sample preparation.

\section{References}

Aljada A, Ghanim H, Mohanty P, Kapur N, Dandona P (2002) Insulin inhibits the pro-inflammatory transcription factor early growth response gene-1 (Egr)-1 expression in mononuclear cells (MNC) and reduces plasma tissue factor (TF) and plasminogen activator inhibitor-1 (PAI-1) concentrations. J Clin Endocrinol Metab 87(3):1419-1422

Aljada A, Ghanim H, Mohanty P, Syed T, Bandyopadhyay A, Dandona P (2004) Glucose intake induces an increase in activator protein 1 and early growth response 1 binding activities, in the expression of tissue factor and matrix metalloproteinase in mononuclear cells, and in plasma tissue factor and matrix metalloproteinase concentrations. Am J Clin Nutr 80(1):51-57

Anderson JW, Baird P, Davis RH Jr, Ferreri S, Knudtson M, Koraym A, Waters V, Williams CL (2009) Health benefits of dietary fiber. Nutr Rev 67(4):188-205

Benjamini Y, Hochberg Y (1995) Controlling the false discovery rate: a practical and powerful approach to multiple testing. J R Stat Soc Series B Stat Methodol 57(1):289-300

Berg JM, Tymoczko JL, Stryer L (2006) Biochemistry, 6th edn. W. H. Freeman and Co Ltd, New York

Biörklund M, van Rees A, Mensink RP, Önning G (2005) Changes in serum lipids and postprandial glucose and insulin concentrations after consumption of beverages with beta-glucans from oats or barley: a randomised dose-controlled trial. Eur J Clin Nutr 59(11):1272-1281

Bonner-Weir S, Li W-C, Ouziel-Yahalom L, Guo L, Weir GC, Sharma A (2010) $\beta$-Cell growth and regeneration: replication is only part of the story. Diabetes 59(10):2340-2348. doi: $10.2337 / \mathrm{db} 10-0084$

Boyd DB (2003) Insulin and cancer. Integr Cancer Ther 2(4):315-329

Caballero B (1993) Vitamin E improves the action of insulin. Nutr Rev 51(11):339-340

Chan MY, Heng CK (2008) Sequential effects of a high-fiber diet with psyllium husks on the expression levels of hepatic genes and plasma lipids. Nutrition (Burbank, Los Angeles County, Calif) 24(1):57-66

de Roos B (2009) Proteomic analysis of plasma, platelets and peripheral blood mononuclear cells in nutritional intervention studies. In: Astley S, Penn L (eds) Design of human nutrigenomics studies. Wageningen Academic Publishers, Wageningen

Eady JJ, Wortley GM, Wormstone YM, Hughes JC, Astley SB, Foxall RJ, Doleman JF, Elliott RM (2005) Variation in gene expression profiles of peripheral blood mononuclear cells from healthy volunteers. Physiol Genomics 22(3):402-411

Gentleman RC, Carey VJ, Bates DM, Bolstad B, Dettling M, Dudoit S, Ellis B, Gautier L, Ge Y, Gentry J, Hornik K, Hothorn T, Huber W, Iacus S, Irizarry R, Leisch F, Li C, Maechler M, Rossini AJ, Sawitzki G, Smith C, Smyth G, Tierney L, Yang JY, Zhang J (2004) Bioconductor: open software development for computational biology and bioinformatics. Genome Biol $5(10): R 80$

Granfeldt Y, Nyberg L, Björck I (2008) Muesli with $4 \mathrm{~g}$ oat betaglucans lowers glucose and insulin responses after a bread meal in healthy subjects. Eur J Clin Nutr 62(5):600-607 
Hallfrisch J, Scholfield DJ, Behall KM (2003) Physiological responses of men and women to barley and oat extracts $(\mathrm{Nu}-$ trimX). II. Comparison of glucose and insulin responses. Cereal Chem 80(1):80-83. doi:10.1094/CCHEM.2003.80.1.80

Juvonen KR, Purhonen AK, Salmenkallio-Marttila M, Lahteenmaki L, Laaksonen DE, Herzig KH, Uusitupa MI, Poutanen KS, Karhunen LJ (2009) Viscosity of oat bran-enriched beverages influences gastrointestinal hormonal responses in healthy humans. J Nutr 139(3):461-466

Kallio P, Kolehmainen M, Laaksonen DE, Kekalainen J, Salopuro T, Sivenius K, Pulkkinen L, Mykkanen HM, Niskanen L, Uusitupa M, Poutanen KS (2007) Dietary carbohydrate modification induces alterations in gene expression in abdominal subcutaneous adipose tissue in persons with the metabolic syndrome: the FUNGENUT Study. Am J Clin Nutr 85(5):1417-1427

Key TJ, Spencer EA (2007) Carbohydrates and cancer: an overview of the epidemiological evidence. Eur J Clin Nutr 61(Suppl 1):S112-S121

Landberg R, Andersson SO, Zhang JX, Johansson JE, Stenman UH, Adlercreutz H, Kamal-Eldin A, Aman P, Hallmans G (2010) Rye whole grain and bran intake compared with refined wheat decreases urinary C-peptide, plasma insulin, and prostate specific antigen in men with prostate cancer. J Nutr 140(12):2180-2186

Makide K, Kitamura H, Sato Y, Okutani M, Aoki J (2009) Emerging lysophospholipid mediators, lysophosphatidylserine, lysophosphatidylthreonine, lysophosphatidylethanolamine and lysophosphatidylglycerol. Prostaglandins Other Lipid Mediat 89(3-4):135-139

Mattisson I, Wirfalt E, Johansson U, Gullberg B, Olsson H, Berglund $\mathrm{G}$ (2004) Intakes of plant foods, fibre and fat and risk of breast cancer-a prospective study in the Malmo diet and cancer cohort. Br J Cancer 90(1):122-127

McGhee NK, Jefferson LS, Kimball SR (2009) Elevated corticosterone associated with food deprivation upregulates expression in rat skeletal muscle of the mTORC1 repressor, REDD1. J Nutr 139(5):828-834

Mohr S, Liew CC (2007) The peripheral-blood transcriptome: new insights into disease and risk assessment. Trends Mol Med 13(10):422-432

Mootha VK, Lindgren CM, Eriksson KF, Subramanian A, Sihag S, Lehar J, Puigserver P, Carlsson E, Ridderstrale M, Laurila E, Houstis N, Daly MJ, Patterson N, Mesirov JP, Golub TR, Tamayo P, Spiegelman B, Lander ES, Hirschhorn JN, Altshuler D, Groop LC (2003) PGC-1alpha-responsive genes involved in oxidative phosphorylation are coordinately downregulated in human diabetes. Nat Genet 34(3):267-273

Morine MJ, O'Brien C, Roche HM (2008) Session 2: personalised nutrition. Transcriptomic signatures that have identified key features of metabolic syndrome. Proc Nutr Soc 67(4):395-403
Rideout TC, Harding SV, Jones PJ, Fan MZ (2008) Guar gum and similar soluble fibers in the regulation of cholesterol metabolism: current understandings and future research priorities. Vasc Health Risk Manag 4(5):1023-1033

Rowles J, Scherer SW, Xi T, Majer M, Nickle DC, Rommens JM, Popov KM, Harris RA, Riebow NL, Xia J, Tsui LC, Bogardus C, Prochazka M (1996) Cloning and characterization of PDK4 on $7 \mathrm{q} 21.3$ encoding a fourth pyruvate dehydrogenase kinase isoenzyme in human. J Biol Chem 271(37):22376-22382

Sadiq Butt M, Tahir-Nadeem M, Khan MK, Shabir R, Butt MS (2008) Oat: unique among the cereals. Eur J Nutr 47(2):68-79

Sofer A, Lei K, Johannessen CM, Ellisen LW (2005) Regulation of mTOR and cell growth in response to energy stress by REDD1. Mol Cell Biol 25(14):5834-5845

Subramanian A, Tamayo P, Mootha VK, Mukherjee S, Ebert BL, Gillette MA, Paulovich A, Pomeroy SL, Golub TR, Lander ES, Mesirov JP (2005) Gene set enrichment analysis: a knowledgebased approach for interpreting genome-wide expression profiles. Proc Natl Acad Sci USA 102(43):15545-15550

R Development Core Team (2008) R: a language and environment for statistical computing. $\mathrm{R}$ foundation for statistical computing. http://www.R-project.org

Theuwissen E, Plat J, Mensink RP (2009) Consumption of oat betaglucan with or without plant stanols did not influence inflammatory markers in hypercholesterolemic subjects. Mol Nutr Food Res 53(3):370-376

Tiganis T (2010) Reactive oxygen species and insulin resistance: the good, the bad and the ugly. Trends Pharmacol Sci (In press, corrected proof). doi: 10.1016/j.tips.2010.11.006

Ulmius M, Johansson A, Önning G (2009) The influence of dietary fibre source and gender on the postprandial glucose and lipid response in healthy subjects. Eur J Nutr 48(7):395-402

US FDA (1997) Food labelling: health claims; soluble fiber from whole oats and risk of coronary heart disease. Fed Regist 62:15343-15344

van Erk MJ, Blom WA, van Ommen B, Hendriks HF (2006) Highprotein and high-carbohydrate breakfasts differentially change the transcriptome of human blood cells. Am J Clin Nutr 84(5):1233-1241

Visvikis-Siest S, Marteau JB, Samara A, Berrahmoune H, Marie B, Pfister M (2007) Peripheral blood mononuclear cells (PBMCs): a possible model for studying cardiovascular biology systems. Clin Chem Lab Med 45(9):1154-1168

Wu Z, Irizarry RA, Gentleman R, Martinez-Murillo F, Spencer F (2004) A model-based background adjustment for oligonucleotide expression arrays. J Am Stat Assoc 99:909-917 